\title{
Secular Stagnation and Google Trends Can We Find Out What People Think?
}

\author{
KATARZYNA SCHMIDT-JESSA \\ Poznań University of Economics and Business*
}

MATEUSZ GAJTKOWSKI

Warsaw School of Economics

\begin{abstract}
The main aim of the study was to verify the thesis that the US economy is measured against the spectre of secular stagnation by determining the mood of American society using Google Trends. While performing the analysis, we used data on the American market for the years 2004-2018. The study comprised 42 entries, including 19 entries from the category "social" and 23 entries from the category "financial". The analyses do not allow for a clear statement that the US economy is facing the spectre of secular stagnation, but they allow us to formulate the observation that the mood of the society is moderately pessimistic, which translates into economic activity measured by GDP what was positively verified with the use of regression analysis in case of social mood index variable.
\end{abstract}

Keywords: secular stagnation, Google Trends, social mood, sentiment

JEL classification: E32, E66, E70

\section{Introduction}

The concept of secular stagnation was first used by Alvin Hansen in 1934 (Hansen, 1934) and then in 1938 during his speech to the American Association of Economists (Hansen, 1939) as an attempt to define the situation of the United States economy at that time.

When in 2013, and later in February 2014, Lawrence Summers used Hansen's words in his speeches at the IMF Forum and the National Association for Business Economics meeting, the economic world flared up (Eichengreen 2014). Summers' arguments advocating the beginning of secular stagnation met with both criticism and recognition, triggering a general discussion in the world of economics and finance. "It suddenly became acceptable to ask previously

\footnotetext{
* Schmidt-Jessa: Department of Money and Banking, The Poznań University of Economics and Business, Poland, katarzyna.schmidt-jessa@ue.poznan.pl; ORCID number: 0000-0002-5310-1038; Gajtkowski: School of Economics, Poland, mg103931@,doktorant.sgh.waw.pl; ORCID number: 0000-0001-79137154

(C) 2021 Katarzyna Schmidt-Jessa and Mateusz Gajtkowski; Licensed under the Creative Commons Attribution - Noncommercial 4.0 Licence (http: //creativecommons.org/licenses/bync/4.0/. Available at http://rofea.org.
} 
unthinkable questions. What if the rates of growth expected by economists and so desired by politicians were no longer available to developed countries? What if sluggish demand was not caused by cyclical underinvestment or debt overhang, inevitable echoes from the 2008 financial crisis? What if it represented a more entrenched change in underlying economic fundamentals? Could an era of falling growth rates in advanced economies be the 'new normal'?" (Jackson 2019, p. 237).

However, before the search for answers to these questions began, it was necessary to understand what led Lawrence Summers to use such a fundamental statement. In the literature three basic factors are given, which would speak in favour of the concept of secular stagnation: structural aggregate demand deficiency (caused by ageing populations, growing income and wealth inequality, and falling tangible investment owing to technological change), growing output gap, and low or even negative equilibrium real interest rate (Borio 2017). The factors presented, however, are nothing else but the effect of human activities and their attitude towards the surrounding world. It should be remembered that "the economy is the sum of the economic interaction in society. One person's decision to, say, buy a car or risk the firm's capital on expansion may not affect the economy. But if the social mood fosters many people to buy cars and expand their business, then the economy expands" (Nofsinger 2005, p. 147). Following the indicated course of thinking, we decided to take a different approach to the subject of secular stagnation. To the best of our knowledge, in existing studies on the phenomenon of secular stagnation in recent years, researchers (Jackson 2019, Acemoglu and Restrepo 2017, Summers 2016, Eichengreen 2015, Mączyńska 2015, Rachel and Smith 2015, Gordon 2014, Summers 2014, Summers 2013) focused solely on macroeconomic indicators proving or failing to prove the existence of a real threat of secular stagnation. This paper presents an innovative approach to this issue by combining the phenomenon of secular stagnation with behavioural finance, using Google Trends, a tool used for many years to determine travel destinations, predictions of the sale of products in online retailing and home sales (Boone et. al. 2018, Choi and Varian 2009) or share prices on the capital markets (Pai, Hong and Lin 2018, Preis, Moat and Stanley 2013), to forecast macroeconomic indicators, including unemployment (Bock 2018), and even flu (Ginsber et al. 2017, Kang et al. 2013). Addressing the issues at hand, we stated that it is worth checking what society, and not macroeconomic indicators, thinks about the existing economic situation in the United States and whether the alleged ubiquitous stagnation and pessimism is the reality they have to face.

The questions thus posed led us to determine the main aim of the paper, i.e. verification of the thesis that the US economy is measured against the spectre of secular stagnation. We intended to make this verification through the determination of the mood of American society using Google Trends.

The paper is divided into five parts. In the first part, we review the literature related to the phenomenon of secular stagnation. The second part presents examples of research conducted 


\section{SCHMIDT-JESSA GAJTKOWSKI Secular Stagnation and Google Trends}

so far using Google Trends. The third part presents the data used and the research methodology. The fourth part presents the results obtained and conclusions drawn from them. The last part is a summary that concludes the study and points to issues that may contribute to further, in-depth analyses.

\section{Secular Stagnation}

When Hansen first wrote about secular stagnation in 1934 (Hansen, 1934), the US economy was at a completely different stage of development. From 1924, the US was in a particularly good economic climate, encouraging entrepreneurs and consumers to invest. At the end of the 1920s, the United States employed 45 million citizens, with total annual revenues of USD 77 million (Zagóra-Jonszta, 2017). There was no indication, therefore, of any slowdown or economic downturn.

That is why, when a violent crash occurred in the prevailing spirit of prosperity, it was not possible to explain what could have caused the famous Great Economic Crisis of the late 1920s and early 1930s. After years of analysis, we know, however, that the main and direct reason for the collapse of the United States economy was banking sector lending, the framework of which was set by the monetary policy conducted by the Federal Reserve System (FED). The low interest rates introduced by the FED enabled economic entities and households to take cheap loans, for which these entities and households purchased shares, causing a sharp and continuous increase in the price of securities (Ibidem). The bursting of the speculative bubble was long and painful, as share prices fell continuously from 1929 to 1932, and the average price of one industrial share fell from \$365 to \$65 in 1933 (Ibidem).

The effects of the Great Depression were spectacular. Over the years, 140,000 factories have collapsed, including 29.3 thousand in the United States (Wojnarski, 2004). Plethora of excellent entrepreneurs and personalities have lost their fortunes while the newspapers have constantly reported suicide and heart attacks among members of the financial elite (Zagóra-Jonszta, 2017). The strenuous attempts to regenerate the economies, additionally hindered by the convertibility of currencies into gold ${ }^{1}$, and the drastic decline in the birth rate in the US, have deepened depressive moods in society. Not surprisingly, in 1934, Alvin Hansen began to mention secular stagnation, which he defined as "sick recoveries which die in their infancy and depression which feed on themselves and leave a hard and seemingly immovable core of unemployment" (Hansen 1393, p. 4). As it turned out, Alvin Hansen was not quite right. Later research showed that the 1930s were characterized by significant technological development, and in 1941 production increased by one third compared to 1929 , which meant systematic development of the economy even taking into account the Great Depression period (Taylor, 2013, after: Field,

\footnotetext{
${ }^{1}$ More about moving away from the gold standard in: Rorhbard M.N. (2016). Złoto, Banki, Ludzie. Krótka historia Pieniądza., 3rd edition, Warsaw: Fijorr Publishing Company
} 
2012). However, Alvin Hansen could not have foreseen that World War II would break out in 1939, resulting in a rapid increase in public spending and fears of insufficient demand would disappear for many years. In this way, the spectrum of secular stagnation was forgotten (Marczewski 2017).

The oblivion lasted until 2013, and specifically to Lawrence Summers' speech at the 14th annual IMF Conference dedicated to the memory of Stanley Fischer ${ }^{2}$, during which the former World Bank Chief economist and US Treasury Secretary decided to comment on the prevailing economic situation in the United States while recalling the concept of secular stagnation. And although Summers began his speech optimistically, emphasizing that the global financial crisis of 2007-2009 was definitely worse in terms of most statistics such as: GDP, industrial production, employment, global trade and stock markets since the Great Depression of 19291933, it was better alleviated and therefore not reminiscent of the situation from years ago, at the same time he noticed that four years after the end of the global financial crisis, the number of employees did not increase, and the GDP is still falling below the potential level. This fact puzzled Summers the more that, according to the classical economic mechanism, after the crisis has ended, the production rate should increase, and the economy should perform significant regeneration (Summers, 2013). Nothing like that happened. In addition, falling real interest rates leading to a significant drop in the natural interest rate pose very serious problems for economies, depriving central banks of conventional monetary policy tools.

The whole was quite a pessimistic picture of the economic situation, which R. J. Gordon compared in 2014 to "the Economist cover of 19 July 2014, showing a frustrated jockey dressed in the colours of the US flag frantically trying to get some movement from the gigantic turtle that he is riding "(Gordon 2014, p. 47).

In addition, a number of structural factors have been pointed out that significantly contribute to the economic slowdown, such as: negative birth rates and an aging society ("An American woman reaching a childbearing age in 1960 would expect 3.6 children; an identical woman would expect 1.9 children in 1990. Today this number stands at 1.8." (Eggertsson, Lancastre and Summers 2018, p.1)) or income inequalities ("By 2015, the richest $10 \%$ of the population received almost 40\% of the national income, higher than any time since 1945" (Jackson 2019, p. 241)).

Of course, among economists, there was also a group of sceptics who believe that secular stagnation does not threaten the American economy. N. Crafts (2014) reports that Europe is more exposed to secular stagnation than the United States, and J. Mokyr (2014) emphasizes that dynamic technological development will overcome obstacles resulting from structural changes. Nobel Prize winner in economics - J. E. Stiglitz (2018) spoke very strongly about

\footnotetext{
${ }^{2}$ This is confirmed by studies illustrating the number of searches for the expression secular stagnation in JSTOR, see: Backhouse R.E., Boianovsky M. (2016), Secular stagnation: The history of a macroeconomic heresy, The European Journal of the History of Economic Thought, 23: 6, 946-970
} 


\section{SCHMIDT-JESSA GAJTKOWSKI Secular Stagnation and Google Trends}

secular stagnation, explicitly rejecting the vision of the spectrum of secular stagnation. He claimed that "secular stagnation was just an excuse for flawed economic policies" (Stiglitz, p. 2). Perhaps, therefore, it is true that "if the US does experience secular stagnation over the next decade or two, it will be self-inflicted" (Eichengreen 2014, p. 41).

\section{Google Trends}

Since the beginning of Google Trends, a lot of research has been conducted based on information from Google search engine. The results of the analysis indicate the usefulness and relevance of data based on Internet users' queries in predicting economic activity or consumer behaviour. To the best of ours knowledge, however, so far, no research has been conducted that would combine the Google Trends tool with the phenomenon of secular stagnation. It seems quite surprising, especially when we take into account the fact that the mood directly influences the decisions taken by business entities (Nofsinger 2005).

Gao, Ren and Zhang (2016) in their study "Googling Investor Sentiment around the World" have analysed how investor sentiment affects stock markets around the world. The study was conducted on 40 economies, using the sentiment index built by Google Trends. By the sentiment index, researchers understood the differences between the mean values for positive and negative words. The selection of words used by the authors in the study was subjective and was based on the terms contained in the Harvard IV-4 Dictionary and the Lasswell Value Dictionary. The results of the study show that local sentiment has an impact in predicting future returns in emerging markets, while global sentiment has a greater impact on developed countries. At the same time, for all 40 economies, "negative relationship between sentiment and the next week's market returns" was demonstrated (Ibidem, p. 3).

A similar study was conducted by Preis, Moat and Stanley (2013) who constructed an investment strategy consisting in the purchase or sale of the Dow Jones Industrial Average index in the years 2004-2011. As part of the presented study, simulations were conducted based on 98 entries, most frequently appearing in the electronic edition of the journal Financial Times. Among the five most common words were: hedge, dividends, earnings, inflation and markets. The simulations carried out confirmed the authors' expectations regarding the utility of Google Trends in the context of data prediction on the capital market. The highest rate of return was achieved in the case of the strategy based on the password of debt, which amounted to $326 \%$, proving to be several times higher than the popular "Buy and Hold" strategy (the achieved rate of return on the implementation of the "Buy and Hold" strategy in the same period was 16\%).

The investment strategy was also built by Bock (2018), who, using the Google Trends tool, verified whether it is possible to build a profitable investment strategy by predicting the likely changes in U.S. unemployment before the official news release. A study based on data from 2004-2017 showed that "the massive new data sources of human interaction with the Internet not only improves U.S. unemployment rate predictability but can also enhance market timing 
of trading strategies when considered jointly with macroeconomic data" (Ibidem, p. 1). At the same time, the author emphasizes that there is significant potential in combining large data sets called behavioural data with economic data, which can be used to predict investors' expectations as well as capital market movements.

A stimulating study was conducted by Pai, Hong, and Lin (2018). The authors combining historical trading data and data from Google Trends created an investment strategy that purpose was to investigate the performance of forecasting stock markets in the US. Keywords employed for Google Trends were collected in three different ways: including users' definitions, trending searches of Google Trends, and tweets. The result of the study indicates that using hybrid data can provide satisfied forecasting results that prove the usefulness of Google Trends data in this study.

A different forecasting study was explored by Ganesham et al. (2018) who checked if data from Google Trends can be used to improve the sales forecasts of specific products in online retailing. The authors studied if the search volumes for certain terms can reduce out-of-sample forecast errors. The premise was that a search for a certain term/product might be combine with an intent to explore and potentially buy the product. The results of the study confirmed the postulated hypothesis and the authors concluded that data from Google Trends contributed to an increase in the effectiveness of the forecast.

Interesting, though a little bit different, studies on the use of Google Trends were conducted by scientists from the US and China. Kang et al. (2013) analysed the correlation between the incidence of influenza and the number of queries for individual terms in the Google search engine in the years 2008-2011. Data on the incidence of diseases came from regional medical centres located in Guangdong Province. The number of queries for individual entries occurring in the same territory was analysed. A similar study was conducted by US researchers: Ginsberg et al. (2017). Both in the case of the study originating from China and the USA, the results confirmed the correlation between the variables studied.

The above research examples indicate that Google Trends is a tool that can be successfully used to predict the near future or may be the key to understanding the present. The biggest difficulty, however, is to isolate such a catalogue of words that can be considered appropriate in the given problems.

\section{Data and Methodology}

The presented study was made applying the Google Trends tool, using the available data for the period 2004-2018 for the US market.

Google has publicly disclosed data on the frequency of terms or phrases entered in Google search engine since 2004. The published information reflects the number of searches for a given word or phrase in relation to the total number of searches in a given period by all Google users. 


\section{SCHMIDT-JESSA GAJTKOWSKI Secular Stagnation and Google Trends}

These data are then normalized to a scale of 0-100 where each data in the analysed period is divided by the highest of the results obtained, which gives the opportunity to observe changes in the search for individual phrases over the years. Therefore, the maximum value determines the point indicated on the time scale in which there were relatively the highest number of queries for a given phrase in relation to all queries in the analysed period. In addition, the tool provides the option of generating a spatial query distribution in accordance with the NUTS2 breakdown, thanks to which information about the place where the given passwords are the most popular becomes available. The above causes that we could carry out the research on any selected market. A detailed description of the analysis is presented below.

The first stage of the study was the selection of a research sample. Through the research sample, we understand groups of words or phrases that could be potentially entered by Google search users in a given period. The choice of entries could not, however, be accidental, since from the research point of view it was very important to determine what concepts users would enter in the search engine in certain moods. In order to isolate the main social moods, we used the study of J. R. Nofsinger (2005), who reports that the sentiment of society can be divided into four phases, called the social mood cycle, they are: increasing mood, peak positive mood, declining mood and peak negative mood. J. R. Nofsinger (2005) described each of these phases using a set of nouns that convey the emotions and mood of society.

Using emotional states in society described by J. R. Nofsinger's (2005), we built a base of 803 words, dividing them into two categories: general words (hereinafter referred to as "social" words) and financial words, and each of these categories was divided into 4 phases of social moods.

Table 1. Emotional characteristic at each phase of the social mood cycle

\begin{tabular}{cccc}
\hline Increasing Mood & Peak Positive Mood & Declining Mood & Peak Negative Mood \\
\hline optimism & overconfidence & pessimism & fear \\
\hline happiness & euphoria & sadness & depression \\
\hline generous & excess & conservtism & stinginess \\
\hline inclusion & ambivalence & exclusion & segregation \\
\hline supportiveness & graciousness & defensivenss & antagonistic \\
\hline hope & trust & suspicion & mistrust \\
\hline
\end{tabular}

Source: Nofsinger J.R. (2005).

\footnotetext{
${ }^{3}$ The initial word selection is fully subjective. The selected words had the nature of associations related with individual emotional states described in detail in Table 1.
} 
To limit the subjectivity associated with the selection of individual words, we decided to conduct a CAWI ${ }^{4}$ study, which aimed to select a detailed group of words or phrases from a given sample of 80 words. Selected words or phrases were subject to further examination. The CAWI survey, which is the second stage of the analysis, was conducted on a sample of 50 respondents, each of whom was asked to answer the question: When an Internet user is accompanied by a mood (indicated one of the four analysed), is there a more than 50\% probability that the Internet user will enter a specific word or phrase to Google search? The indicated question was asked to the respondent eight times, and each question was answered with 10 words (the survey constitutes Appendix 1). For further analysis, we selected terms for which the answer was over $50 \%$ positive. The separated groups of words are in the table below.

Table 2. Terms selected for analysis

\begin{tabular}{|c|c|c|c|c|c|c|c|}
\hline \multicolumn{8}{|c|}{ Social } \\
\hline \multicolumn{2}{|c|}{ Increasing Mood } & \multicolumn{2}{|c|}{ Peak Positive Mood } & \multicolumn{2}{|c|}{ Declining Mood } & \multicolumn{2}{|c|}{ Peak Negative Mood } \\
\hline $\begin{array}{l}\text { all-inclusive } \\
\text { resorts }\end{array}$ & $82 \%$ & $\begin{array}{c}\text { mega millions } \\
\text { winning numbers }\end{array}$ & $56 \%$ & healing & $52 \%$ & job loss & $72 \%$ \\
\hline best comedy & $80 \%$ & world trip & $84 \%$ & work abroad & $64 \%$ & $\begin{array}{l}\text { sleeping } \\
\text { difficulty }\end{array}$ & $80 \%$ \\
\hline gifts & $62 \%$ & new apartments & $64 \%$ & $\begin{array}{l}\text { best drama } \\
\text { movies }\end{array}$ & $54 \%$ & psychologist & $78 \%$ \\
\hline surprise ideas & $60 \%$ & land for sale & $66 \%$ & job offer & $76 \%$ & $\begin{array}{c}\text { workers } \\
\text { compensation }\end{array}$ & $52 \%$ \\
\hline $\begin{array}{l}\text { goodwill } \\
\text { donations }\end{array}$ & $52 \%$ & concert tickets & $66 \%$ & $\begin{array}{c}\text { workplace } \\
\text { issues }\end{array}$ & $58 \%$ & & \\
\hline \multicolumn{8}{|c|}{ Financial } \\
\hline \multicolumn{2}{|c|}{ Increasing Mood } & \multicolumn{2}{|c|}{ Peak Positive Mood } & \multicolumn{2}{|c|}{ Declining Mood } & \multicolumn{2}{|c|}{ Peak Negative Mood } \\
\hline brokerage account & $54 \%$ & investment funds & $64 \%$ & tax advisor & $60 \%$ & bankruptcy & $74 \%$ \\
\hline stock & $66 \%$ & startup & $70 \%$ & $\begin{array}{c}\text { credit } \\
\text { consolidation }\end{array}$ & $60 \%$ & $\begin{array}{c}\text { pyramid } \\
\text { scheme }\end{array}$ & $54 \%$ \\
\hline $\begin{array}{l}\text { the best } \\
\text { investment }\end{array}$ & $76 \%$ & $\begin{array}{l}\text { alternative } \\
\text { investment }\end{array}$ & $54 \%$ & $\begin{array}{l}\text { financial } \\
\text { advisor }\end{array}$ & $68 \%$ & crisis & $80 \%$ \\
\hline $\begin{array}{l}\text { high return } \\
\text { investment }\end{array}$ & $70 \%$ & dividend & $54 \%$ & payday loan & $68 \%$ & dismissal & $78 \%$ \\
\hline high profit margin & $74 \%$ & & & & & $\begin{array}{c}\text { corporate } \\
\text { restructuring }\end{array}$ & $64 \%$ \\
\hline startup grants & $66 \%$ & & & & & repo man & $66 \%$ \\
\hline start a business & $78 \%$ & & & & & credit card & $60 \%$ \\
\hline $\begin{array}{c}\text { llc sole } \\
\text { proprietorship }\end{array}$ & $72 \%$ & & & & & & \\
\hline
\end{tabular}

Source: own compilation based on CAWI survey.

\footnotetext{
${ }^{4}$ The CAWI survey was conducted in Poland in the period 09.2019-10.2019 - the survey was bilingual.
} 


\section{SCHMIDT-JESSA GAJTKOWSKI Secular Stagnation and Google Trends}

The third stage of the study was to implement the extracted words or phrases into the Google Trends tool. As described above, the Google tool provides data that is normalized on a scale of 0 -100. Therefore, in order to determine changes occurring in the attitudes accompanying the society in the USA, for each word, for each year from the analysed time series, a normalized level of searches was determined. Then, we verified the annual differences in the level of popularity of given phrases, using the scale created for the purposes of the study. The need to use the scale resulted from the need to take into account the level of significance of individual changes between periods. Based on the statistical analysis of the received data, we concluded that the annual change by $|0-3|$ units is the change with the smallest impact force and assigned its value $|1|$, and the annual change by $|12-100|^{5}$ units is the change with the greatest impact and assigned its value $|5|$. At the same time, it was decided to assign appropriate weights to individual social moods. For increasing mood and declining mood the weight was 1 , and for peak positive mood and peak negative mood 1.5. Details are presented in the table below.

After developing a scale of appropriate sensitivity, we assigned normalized changes corresponding values (for each word/expression), and then calculated the overall, average change for each phase of social mood (average for all words in a given phase). In consequences, results were obtained for 14 periods divided into two main categories and four phases determining the social mood.

Table 3. The scale used in analysis

\begin{tabular}{cccccc}
\hline $\begin{array}{c}\text { Range of changes in } \\
\text { standardized units }\end{array}$ & Value & Weight & $\begin{array}{c}\text { Increasing } \\
\text { mood } \\
\text { Declining } \\
\text { mood }\end{array}$ & $\begin{array}{c}\text { Peak positive } \\
\text { mood } \\
\text { Peak negative } \\
\text { mood }\end{array}$ \\
\hline $\min$ & -12 & -5 & $1-1.50$ & -5 & -7.50 \\
\hline-12 & -9 & -4 & $1-1.50$ & -4 & -6.00 \\
\hline-9 & -6 & -3 & $1-1.50$ & -3 & -4.50 \\
\hline-6 & -3 & -2 & $1-1.50$ & -2 & -3.00 \\
\hline-3 & 0 & -1 & $1-1.50$ & -1 & -1.50 \\
\hline 0 & +3 & 1 & $1-1.50$ & 1 & 1.50 \\
\hline+3 & +6 & 2 & $1-1.50$ & 2 & 3.00 \\
\hline+6 & +9 & 3 & $1-1.50$ & 3 & 4.50 \\
\hline+9 & +12 & 4 & $1-1.50$ & 4 & 6.00 \\
\hline+12 & $\max$ & 5 & $1-1.50$ & 5 & 7.50 \\
\hline
\end{tabular}

Source: own compilation.

\footnotetext{
${ }^{5}$ The maximum change in the "social" sample was 26 units, and in the "financial" sample 30 units.
} 
In order to verify whether the results obtained can be considered reliable, we decided that the next and final step of the study will be to build a linear regression model. The dependent variable in the model is the GDP of the United States, and the independent variables are the sentiment indexes determined for the "social" and "financial" categories, respectively. Macroeconomic GDP data were retrieved from the World Bank database.

The social and financial mood from year $t-1$ should influence the level of GDP in the year $t$ therefore the verified regression equation (1) was as follows:

$$
G D P_{t}=\beta_{0}+\beta_{1} S M_{t-1}+\beta_{2} F M_{t-1}+\varepsilon_{t}
$$

where SM is social mood index and FM is financial mood index.

\section{Results}

The results are presented in two parts. In the first part, we show the indexes for social and financial sentiment with a short description, and then in the second part, we focus on the results obtained from the regression analysis.

\subsection{Social and financial mood indexes}

The analysis of data showed a different development of sentiments occurring in the society, both in the case of the analysis of terms from the group of "social" and "financial". At the same time, when interpreting the data below, it should be remembered that:

- a positive change in the result for terms from the phase of increasing mood and peak positive mood means an improvement in mood,

- a negative change in the result for terms from the phase of increasing mood and peak positive mood means a worsening of the mood,

- a positive change in the result for the terms from the declining mood and peak negative mood phase means a worsening of the mood,

- a negative change in the result for terms from the declining mood and peak negative mood phase means an improvement in the mood.

The above interpretation made it possible to sum up individual values within "social" and "financial" groups in categories: "positive mood" - positive values and "negative mood" negative values. The final conclusions were drawn upon the determination of the average final value for each year.

\section{Social mood}

Analyzing the category of social words (table 4. and figure 1.), one should notice a fairly faithful reflection of the prevailing historical moods. A clear increase in searching for words with negative connotations occurred in the years of the financial crisis 2008-2009. The indicated trend continued in 2010. In 2011, there was a fundamental increase in the social mood, which 


\section{SCHMIDT-JESSA GAJTKOWSKI Secular Stagnation and Google Trends}

means that American society more often searched for words with a positive resonance. Starting from 2012 until the end of 2018, the mood of American society should be considered moderately pessimistic. It is worth noting, however, that in 2012 and 2017 the sentiment of the society was relatively neutral.

Table. 4. Results of research for "social" terms

\begin{tabular}{cccccc}
\hline Year & $\begin{array}{c}\text { Increasing } \\
\text { mood }\end{array}$ & $\begin{array}{c}\text { Peak positive } \\
\text { mood }\end{array}$ & $\begin{array}{c}\text { Social } \\
\text { Declining } \\
\text { mood }\end{array}$ & $\begin{array}{c}\text { Peak Negative } \\
\text { Mood }\end{array}$ & $\begin{array}{c}\text { Summar } \\
\text { (SM) }\end{array}$ \\
\hline $\mathbf{2 0 0 5}$ & 0.40 & 1.50 & -1.40 & -1.88 & 2.59 \\
\hline $\mathbf{2 0 0 6}$ & -1.60 & -2.40 & -1.60 & -4.50 & 1.05 \\
\hline $\mathbf{2 0 0 7}$ & 0.40 & -0.60 & -0.40 & -0.75 & 0.68 \\
\hline $\mathbf{2 0 0 8}$ & -0.60 & -2.10 & 0.40 & 4.13 & -3.61 \\
\hline $\mathbf{2 0 0 9}$ & -0.20 & 1.20 & 0.40 & 1.50 & -0.45 \\
\hline $\mathbf{2 0 1 0}$ & -1.60 & -0.60 & 0.40 & -1.50 & -0.55 \\
\hline $\mathbf{2 0 1 1}$ & 1.60 & 2.10 & 0.80 & -1.13 & 2.01 \\
\hline $\mathbf{2 0 1 2}$ & 1.00 & -2.10 & -0.20 & -0.38 & -0.26 \\
\hline $\mathbf{2 0 1 3}$ & 0.20 & -0.30 & 1.20 & 1.50 & -1.40 \\
\hline $\mathbf{2 0 1 4}$ & 0.20 & 0.30 & 1.40 & 0.00 & -0.45 \\
\hline $\mathbf{2 0 1 5}$ & -1.00 & 0.60 & 0.20 & 0.00 & -0.30 \\
\hline $\mathbf{2 0 1 6}$ & -0.60 & 0.60 & -0.20 & 0.75 & -0.28 \\
\hline $\mathbf{2 0 1 7}$ & 1.60 & 1.20 & 1.80 & 0.75 & 0.13 \\
\hline $\mathbf{2 0 1 8}$ & -0.60 & 0.60 & 0.60 & 0.38 & -0.49 \\
\hline
\end{tabular}

Source: own compilation.

Figure 1. Results of research for "social" terms combined with the GDP of the US

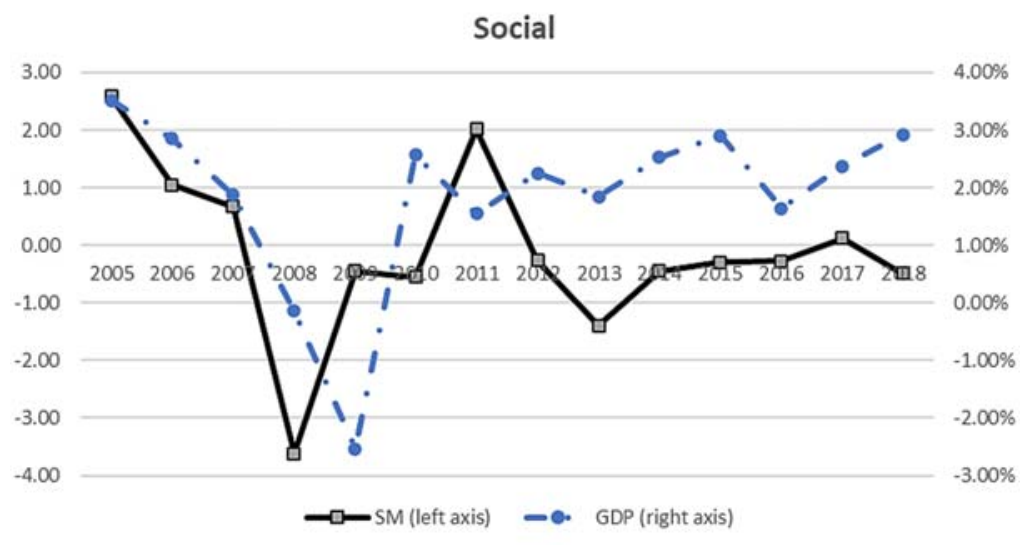

Source: own compilation. 
Taking into account the above results, we stated that the selected words in the category of "social" were selected in a proper way. General sentiment, studied within this category of words, fully confirms the course of historical events. The analysis of the social mood of recent years helps notice that society is not optimistic about the current economic situation, as Google users more often searched for negative words. At the same time, it should be stressed that we are not dealing with a sudden breakdown, which could indicate a crisis. Moreover, since the social mood is moderately pessimistic, it does not seem that there is a risk of another collapse. According to the observations, the crisis occurs after high levels of optimism. This picture is therefore part of the economic stagnation attributed to the USA and the uncertainty about future development.

\section{Financial mood}

An analogous analysis of the words from the financial category (table 5. and figure 2.) showed a much greater dynamics of changes. Negative moods in American society were already present before the financial crisis, since 2005. A clear collapse occurred in 2008 , i.e. during the crisis. However, there are significant fluctuations in the frequency of searching for given words over the next few years and the deep breakdown in 2016. In 2016, the average index for the surveyed words was -2.38 , which is a worse result than in 2008. This result may have its justification in economic events that were unexpected and took place in 2016, namely: the election of Donald Trump as the president of the USA and the vote of Brexit in Great Britain.

Table 5. Results of research for "financial" terms

\begin{tabular}{cccccc}
\hline Year & $\begin{array}{c}\text { Increasing } \\
\text { mood }\end{array}$ & $\begin{array}{c}\text { Peak positive } \\
\text { mood }\end{array}$ & $\begin{array}{c}\text { Declining } \\
\text { mood }\end{array}$ & $\begin{array}{c}\text { Peak Negative } \\
\text { Mood }\end{array}$ & $\begin{array}{c}\text { Summar } \\
\text { (FM) }\end{array}$ \\
\hline $\mathbf{2 0 0 5}$ & -1.75 & -3.75 & -0.50 & -1.29 & -1.86 \\
\hline $\mathbf{2 0 0 6}$ & -0.63 & -3.38 & 1.50 & -2.79 & -1.36 \\
\hline $\mathbf{2 0 0 7}$ & 0.50 & -1.13 & 1.75 & 0.00 & -1.19 \\
\hline $\mathbf{2 0 0 8}$ & -0.38 & 0.38 & 0.75 & 3.64 & -2.20 \\
\hline $\mathbf{2 0 0 9}$ & 0.75 & -3.00 & -1.50 & 2.36 & -1.55 \\
\hline $\mathbf{2 0 1 0}$ & -0.13 & -1.50 & -2.00 & -1.50 & 0.94 \\
\hline $\mathbf{2 0 1 1}$ & 1.00 & -1.13 & 0.25 & 0.43 & -0.40 \\
\hline $\mathbf{2 0 1 2}$ & 1.63 & -0.38 & -0.50 & -0.86 & 1.30 \\
\hline $\mathbf{2 0 1 3}$ & 0.88 & 0.00 & 1.25 & 0.64 & -0.51 \\
\hline $\mathbf{2 0 1 4}$ & 1.25 & 1.88 & 0.75 & 1.07 & 0.65 \\
\hline $\mathbf{2 0 1 5}$ & 0.38 & 0.75 & 0.75 & 0.64 & -0.13 \\
\hline $\mathbf{2 0 1 6}$ & 0.13 & -1.88 & 1.50 & 1.50 & -2.38 \\
\hline $\mathbf{2 0 1 7}$ & 3.38 & 1.88 & 3.25 & 1.93 & 0.04 \\
\hline $\mathbf{2 0 1 8}$ & 1.00 & -1.13 & -0.25 & 0.21 & -0.04 \\
\hline
\end{tabular}

Source: own compilation. 


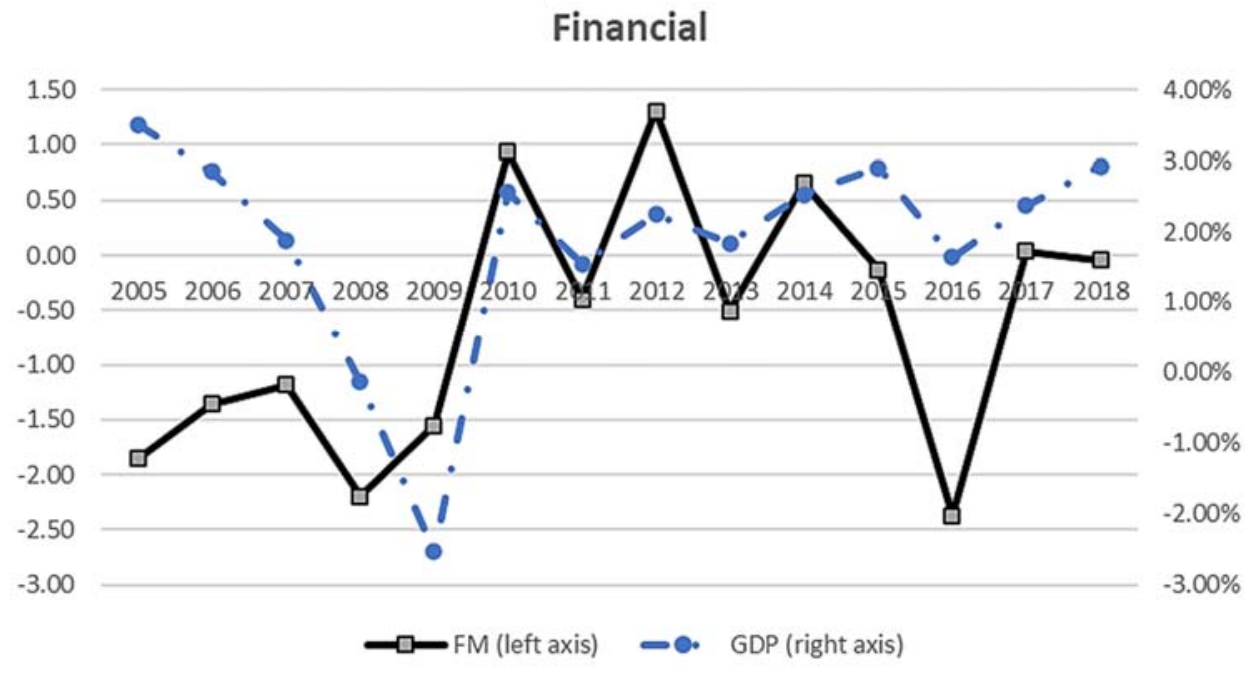

Source: own compilation.

The results concerning the category of 'financial' words do not allow for an unambiguous interpretation. It seems that the search for specialist, financial words by American society is subject to random fluctuations. On the other hand, it is possible that the catalogue of words used was inappropriate. However, the fact that the 2008 and 2016 collapses were sharply in line with historical events may be puzzling. Taking the above into account, in our opinion, "financial" searches are characterized by a high dynamic of change due to the specificity of the analyzed category. Any positive and negative information is reflected in the market, and the lack of clearly positive signals suggests pessimism of the society.

\subsection{Regression results}

The results of the performed regression analysis confirm the preliminary conclusions we drew based on the observation of the figures. The directional coefficient at the SM variable showed statistical significance for the level $\rho=0.05$, while the directional coefficient at the FM variable proved to be insignificant. At the same time, we observed that the effect of the SM variable on GDP is positive, that is, the better the mood in the American society in year $t-1$, the higher the predicted GDP level in year $t$. 
Table 6. Regression results.

\begin{tabular}{lc}
\hline \multicolumn{2}{c}{ Regression Statistics } \\
\hline Multiple R & 0.6527 \\
R square & 0.4260 \\
Adjusted R square & 0.3112 \\
Standard Error & 0.0126 \\
Observations & 13 \\
\hline
\end{tabular}

ANOVA

\begin{tabular}{lccccc}
\hline & $d f$ & $S S$ & $M S$ & $F$ & Significance $F$ \\
\hline Regression & 2 & 0.0012 & 0.0006 & 3.7108 & 0.0623 \\
Residual & 10 & 0.0016 & 0.0002 & & \\
Total & 12 & 0.0028 & & & \\
\hline
\end{tabular}

\begin{tabular}{lcccccc}
\hline & Coefficients & Standard Error & t Stat & P-value & Lower 95\% & Upper 95\% \\
\hline Intercept & 0.0203 & 0.0041 & 5.0068 & 0.0005 & 0.0113 & 0.0293 \\
SM & 0.0057 & 0.0024 & 2.3996 & 0.0373 & 0.0004 & 0.0110 \\
FM & 0.0038 & 0.0030 & 1.2352 & 0.2450 & -0.0030 & 0.0105 \\
\hline
\end{tabular}

Source: own compilation.

\section{Conclusions}

The main aim of the study was to verify the thesis that the US economy is measured against the spectre of secular stagnation by determining the mood of American society using Google Trends.

We carried out the analysis using Google Trends based on data on the American market for the years 2004-2018. The study comprised 42 entries, including 19 entries from the category "social" and 23 entries from the category "financial". The choice of analyzed words/expressions was two-stage, the first of which consisted in the subjective selection of a large group of words by us, and the second consisted of a CAWI survey, in which respondents selected specific phrases according to the question asked in the questionnaire.

The results of the study showed a different development of sentiments in society, both in the case of the analysis of terms from the "social" and "financial" groups. The analysis of the "social" category revealed a good adjustment of the social mood line to the course of historical events. In the case of the "financial" category, a high dynamic of change was observed, which makes it difficult to make unequivocal interpretation. Indicated was confirmed by regression analysis. The sentiment index determined for the "social mood" category showed statistical significance, while the index contracted for the "financial mood" category did not show such 


\section{SCHMIDT-JESSA GAJTKOWSKI Secular Stagnation and Google Trends}

significance. Nevertheless, in both cases it is clear that nowadays the American society shows moderately pessimistic moods.

The analyses carried out do not allow for a clear statement that the US economy is facing the spectre of secular stagnation, but they make it possible to state that the moods of the society are moderately pessimistic, which translates into economic activity measured by GDP. According to the thesis "positive moods lead to productive activities, while negative moods lead to unproductive ones" (Nofsinger 2005, p. 147), the current mood of American society will not contribute to rapid economic growth or development. Bearing this in mind, the question arises, however, whether, as B. Eicheengreen said (2014), we are dealing with a self-fulfilling prophecy and the effect of herd behaviour (Banerjee 1992), or whether perhaps the actual social and economic conditions contribute to a slow, declining economic growth and the spectre of secular stagnation becomes apparent.

It seems that only further in-depth research into social behaviour and secular stagnation, as well as observation of changes and emerging trends, can bring scientists closer to answering these questions. Undoubtedly, however, tracking and researching large data sets available through web-based tools is a potential that should be used in social sciences.

\section{References}

Acemoglu Daron and Restrepo Pascual (2017), Secular stagnation? The effect of aging on economic growth in the age of automation, American Economic Review, 107(5), 174-79.

Backhouse E. Roger and Boianovsky Mauro (2016), Secular stagnation: The history of a macroeconomic heresy, The European Journal of the History of Economic Thought, 23:6, 946-970

Banerjee, V. Abhijit (1992), A simple model of herd behavior. The Quarterly Journal of Economics, 107(3), 797-817.

Bock Johannes (2018), Quantifying macroeconomic expectations in stock markets using Google Trends, Behavioral \& Experimental Finance eJournal.

Boone Tonya, Ganeshan Ram, Hicks L. Robert and Sanders R. Nada (2018), Can Google Trends Improve Your Sales Forecast? Production and Operations Management, 27(10), 1770-1774.

Borio Claudio (2017), Secular stagnation or financial cycle drag? Business Economics, 52(2), $87-98$

Choi Hyunyoung and Varian Hal (2012), Predicting the present with Google Trends. Economic Record, 88, 2-9.

Crafts Nicholas (2014), Secular stagnation: US hypochondria, European disease? in: Teuling Coen and Baldwin Richard (eds.). (2014), Secular Stagnation: Facts, Causes and Cures, London: CEPR Press, 91-97. 
Eggertsson B. Gauti, Lancastre Manuel and Summers H. Lawrance (2018), Aging, output per capita and secular stagnation (No. 24902). National Bureau of Economic Research.

Eichengreen Barry (2014), Secular stagnation: A review of the issues, w: Teuling Coen and Baldwin Richard (eds.). (2014), Secular Stagnation: Facts, Causes and Cures, London: CEPR Press, 41-46.

Eichengreen Barry (2015), Secular stagnation: the long view. American Economic Review, 105(5), 66-70.

Gao Zhenyu, Ren Haogan and Zhang Bohui (2016), Googling investor sentiment around the world. Journal of Financial and Quantitative Analysis, 1-66.

Ginsberg Jeremy, Mohebbi Matthew, Patel Rajan, Brammer Lynmette, Smolinski Mark and Brilliant Larry (2017), Detecting influenza epidemics using search engine query data, Nature, 457 (7232).

Gordon J. Robert (2014), The tutrle's progress: Secular stagnation meets the headwinds, in: Teuling Coen and Baldwin Richard (eds.). (2014), Secular Stagnation: Facts, Causes and Cures, London: CEPR Press, s. 47-59.

Hansen H. Alvin (1934), Capital goods and the restoration of purchasing power. Proceedings of the Academy of Political Science, 16 (1), 11-19.

Hansen H. Alvin (1939), Economic progress and declining population growth. The American Economic Review, 29 (1), 1-15.

Jackson Tim (2019), The post-growth challenge: secular stagnation, inequality and the limits to growth. Ecological Economics, 156, 236-246.

Kang Min, Zhong Haojie., He Jianfeng, Rutherford Shannon and Yang Fen (2013), Using Google Trends for Influenza Surveillance in South China, PLoS ONE, 8(1): e55205.

Marczewski Krzysztof (2017), Hipoteza o stagnacji sekularnej. Studia Ekonomiczne, (4), 377398.

Mączyńska Elżbieta (2015), Potencjał rozwojowy Polski w kontekście hipotezy o nowej sekularnej stagnacji. Zeszyty Naukowe Uniwersytetu Szczecińskiego nr 854, Finanse, Rynki Finansowe, Ubezpieczenia nr 73, 933-946.

Mokyr Joel (2014), Secular stagnation? Not in your life, in: Teuling Coen and Baldwin Richard (eds.). (2014), Secular Stagnation: Facts, Causes and Cures, Londyn: CEPR Press, 83-89.

Nofsinger R. John (2005), Social mood and financial economics. The Journal of Behavioral Finance, 6(3), 144-160.

Pai Ping-Feng, Hong Ling-Chunag and Lin Kuo-Ping (2018), Using Internet search trends and historical trending data for predicting stock markets by the least squares support vector regression model. Computational Intelligence and Neuroscience, vol. 2018, 1-15.

Preis Tobias, Moat S. Hellen and Stanley H. Eugene (2013), Quantifying trading behavior in financial markets using Google Trends. Scientific reports, 3, 1684. 
SCHMIDT-JESSA GAJTKOWSKI Secular Stagnation and Google Trends

Rachel Lukasz and Smith Thomas (2015), Secular drivers of the global real interest rate., Staff Working Paper No. 571, Bank of England.

Rorhbard N. Murray (2016), Złoto, Banki, Ludzie. Krótka Historia Pieniq̨dza. wydanie trzecie, Warszawa: Fijorr Publishing Company.

Stiglitz E. Joseph (2018), The myth of secular stagnation. Project Syndicate, 28.

Summers H. Lawrence (2013), Speech at: IMF Fourteenth Annual Research Conference in Honor of Stanley Fischer http://larrysummers.com/imf-fourteenth-annual-researchconference-in-honor-of-stanley-fischer/.

Summers H. Lawrence (2014), Reflections on the New Secular Stagnation Hypothesis, in: Teuling C., \& Baldwin R. (eds.). Secular Stagnation: Facts, Causes and Cures, London: CEPR Press, 27-38.

Summers H. Lawrence (2016), Secular stagnation and monetary policy., Federal Reserve Bank of St. Louis Review, Second Quarter, 93-110.

Taylor Timothy (2013), Secular Stagnation: Back to Alvin Hansen, http://conversableeconomist.blogspot.com/2013/12/secular-stagnation-back-to-alvinhanson.html.

The World Bank database. (n.a.), GDP growth (annual \%) - United States. Access: https://data.worldbank.org/indicator/NY.GDP.MKTP.KD.ZG?end=2019\&locations=US\& start $=2005$.

Wojnarski Dariusz (2004), Powszechna historia gospodarcza, Warszawa: Wydawnictwo POLTEXT.

Zagóra-Jonszta Urszula (2017), Przyczyny, przebieg i skutki wielkiego kryzysu gospodarczego, in: Gruszczyk Marcela, Krzyżanowski Lech and Skrzypek Miłosz (eds). Europa XX-XXI wieku. Społeczno-polityczne konsekwencje kryzysów, Katowice: Wydawnictwo Uniwersytetu Śląskiego. 


\section{Appendix 1}

\section{Questionnaire}

\section{Social terms - Increasing Mood}

When an Internet user is accompanied by an increasing mood, is there a more than $50 \%$ probability that the Internet user will enter a specific word or phrase to Google search?

\begin{tabular}{l|c}
\hline \multicolumn{1}{c|}{ Social terms - Increasing Mood } & Yes/No \\
\hline all-inclusive holidays & \\
\hline comedy movies & \\
\hline gift ideas & \\
\hline surprise ideas & \\
\hline long-term loans & \\
\hline charitable givings & \\
\hline volunteer program & \\
\hline donations & \\
\hline adult education & \\
\hline
\end{tabular}

\section{Social terms - Peak Positive Mood}

When an Internet user is accompanied by a peak positive mood, is there a more than $50 \%$ probability that the Internet user will enter a specific word or phrase to Google search?

\begin{tabular}{l|c}
\hline \multicolumn{1}{c|}{ Social terms - Peak Positive Mood } & Yes/No \\
\hline mega millions & \\
\hline world trip & \\
\hline yacht & \\
\hline new apartments & \\
\hline environmental protection & \\
\hline pregnancy & \\
\hline baby & \\
\hline ferrari & \\
\hline concert & \\
\hline
\end{tabular}


SCHMIDT-JESSA GAJTKOWSKI Secular Stagnation and Google Trends

Social terms - Declining mood

When an Internet user is accompanied by a declining mood, is there a more than $50 \%$ probability that the Internet user will enter a specific word or phrase to Google search?

\begin{tabular}{l|c}
\hline \multicolumn{1}{c|}{ Social terms - Declining mood } & Yes/No \\
\hline miracles & \\
\hline healing & \\
\hline working abroad & \\
\hline drama movies & \\
\hline labor department & \\
\hline job offers & \\
\hline building self-confidence & \\
\hline workplace issues & \\
\hline betrayal & \\
\hline
\end{tabular}

\section{Social terms - Peak negative mood}

When an Internet user is accompanied by a peak negative mood, is there a more than $50 \%$ probability that the Internet user will enter a specific word or phrase to Google search?

\begin{tabular}{l|c}
\hline \multicolumn{1}{c|}{ Social terms - Peak negative mood } & Yes/No \\
\hline security services & \\
\hline terrorist attacks & \\
\hline job loss & \\
\hline sleeping difficulty & \\
\hline psychologist & \\
\hline suicide & \\
\hline alcoholism & \\
\hline lawyer & \\
\hline strike & \\
\hline insurance compensation & \\
\hline
\end{tabular}




\section{Finance terms - Increasing Mood}

When an Internet user is accompanied by an increasing mood, is there a more than $50 \%$ probability that the Internet user will enter a specific word or phrase to Google search?

\begin{tabular}{l|c}
\hline \multicolumn{1}{c|}{ Finance terms - Increasing Mood } & Yes/No \\
\hline brokerage account & \\
\hline stocks & \\
\hline best investment & \\
\hline high return investments & \\
\hline high profit margin & \\
\hline start-up grants & \\
\hline business angel & \\
\hline start a business & \\
\hline long-term strategy & \\
\hline
\end{tabular}

Finance terms - Peak positive mood

When an Internet user is accompanied by a peak positive mood, is there a more than $50 \%$ probability that the Internet user will enter a specific word or phrase to Google search?

\begin{tabular}{l|c}
\hline \multicolumn{1}{c|}{ Finance terms - Peak Positive Mood } & Yes/No \\
\hline futures contracts & \\
\hline private equity & \\
\hline investment funds & \\
\hline start-up & \\
\hline alternative investments & \\
\hline corporate social responsibility & \\
\hline dividend & \\
\hline securitized products & \\
\hline verivatives & \\
\hline
\end{tabular}


SCHMIDT-JESSA GAJTKOWSKI Secular Stagnation and Google Trends

\section{Finance terms - Declining mood}

When an Internet user is accompanied by a declining mood, is there a more than $50 \%$ probability that the Internet user will enter a specific word or phrase to Google search?

\begin{tabular}{l|c}
\hline \multicolumn{1}{c|}{ Finance terms - Declining mood } & Yes/No \\
\hline tax advisor & \\
\hline us treasuries & \\
\hline deposits & \\
\hline debt consolidation & \\
\hline legal advisor & \\
\hline debt collection & \\
\hline payday loan & \\
\hline fiscal control & \\
\hline audit & \\
\hline
\end{tabular}

\section{Finance terms - Peak negative mood}

When an Internet user is accompanied by a peak negative mood, is there a more than 50\% probability that the Internet user will enter a specific word or phrase to Google search?

\begin{tabular}{l|c}
\hline \multicolumn{1}{c|}{ Finance terms - Peak negative mood } & Yes/No \\
\hline bankruptcy & \\
\hline pyramid scheme & \\
\hline crisis & \\
\hline employee dismissal & \\
\hline restructuring & \\
\hline tax fraud & \\
\hline money laundering & \\
\hline repo man & \\
\hline credit card & \\
\hline
\end{tabular}

